\title{
PENGELOMPOKAN DATA ANGIN PUTING BELIUNG DENGAN MENGGUNAKAN LVQ
}

\author{
Fenny Fitriani \\ Fakultas Keguruan dan Ilmu Pendidikan, Univeritas PGRI Adi Buana Surabaya \\ email: fennyftiriani@gmail.com
}

\begin{abstract}
Abstrak
Pada tahun 2007, Puslitbang - BMKG merintis kegiatan kerja kajian cuaca ekstrim (Puslitbang, 2007). Dalam penelitian tersebut, didapatkan basis data cuaca ekstrim yang berdampak buruk terhadap sektor kehidupan masyarakat. Salah satu dampak tersebut adalah munculnya angin puting beliung yang terjadi di beberapa daerah. Penelitian akan pengelompokan data terjadinya angin puting beliung dapat membantu penelitian selanjutnya untuk digunakan sebagai dasar pembentukan suatu pola perkiraan terjadinya angin puting beliung. Pengelompokan data apda penelitian ini dilakukan dengan menggunakan salah satu algoritma yang ada di jaringan syaraf tiruan, yaitu learning vector quantization (LVQ). Data yang diolah dalam penelitian ini merupakan data cuaca yang terjadi pada persekitaran terjadinya puting beliung. Data yang didapatkan dinormalkan dahulu, lalu diolah dengan algoritma. Hasil pengolahan dengan LVQ ini diharapkan dapat membentuk suatu pola yang bisa digunakan untuk dijadikan pedoman dalam pengolahan data angin puting beliung pada penelitian lebih lanjut.
\end{abstract}

Keywords: $L V Q$, jaringan syaraf tiruan, puting beliung, data kejadian.

\section{PENDAhUluAN}

Akibat terjadinya pemanasan global, maka cuaca yang terjadi menjadi kurang bersahabat. Puslitbang-BMKG merintis kegiatan kerja kajian cuaca ekstrim (Puslitbang, 2007). Hasil dalam penelitian tersebut adalah didapatkan basis data cuaca ekstrim yang berdampak buruk bagi masyarakat. Angin puting beliung merupakan salah satu kejadian yang disebabkan oleh cuaca ekstrim.

Angin puting beliung ini dapat terjadi akibat adanya pertemuan udara dingin dan panas. Biasnya angin puting beliung ini juga disertai dengan curah hujan berintensitas tinggi (Puslitbang, 2009). Fenomena terjadinya angin puting beliung bersifat lokal, mencakup area antara 5-10 km. Puting beliung dapat didefinisikan sebagai angin kencang yang muncul secara tiba-tiba, yang mempunyai pusat, bergerak melingkar seperti spiral hingga menyentuh permukaan bumi. Periode hidup dari angin puting beliung ini tergolong sangat singkat, yaitu sekitar 3 - 5 menit, mulai dari tumbuh hingga punahnya. Periode hidup yang sangat singkat tersebut tidak berarti kerugian yang diakibat sedikit. Sesuai dengan data yang ada, kerugian yang diakibatkan oleh fenomena angin puting beliung ini dapat mencapai ratusan juta rupiah. Seperti yang terjadi di kabupaten Wonogiri pada tanggal 1 Juni 2015, menurut data BNPB terdapat 2 kerusakan berat dan 12 kerusakan ringan pada rumah penduduk. Pada tanggal yang sama, di kabupaten Solok 3 rumah rusak parah akibat angin puting beliung.

Berdasarkan hal tersebut, pada penelitian ini akan di lakukan suatu untuk mengelompokkan secara teliti data kejadian angin puting beliung. Metode yang digunakan adalah algoritma LVQ, dimana LVQ merupakan salah satu algoritma yang ada dalam jaringan syaraf tiruan. Pengelompokan awal dari data yang diambil adalah dengan memberikan pengelompokan kasar sesuai dengan kejadian yang terjadi. Data yang ada tersebut dinormalisasikan terlebih dahulu menjadi bentuk 0 dan 1 . Setelah penormalan tersebut, maka data dibagi menjadi dua yaitu data yang digunakan sebagai data uji dan data training. Kedua data tersebut yang akan diolah untuk menentukan pengelompokan yang diinginkan dengan menggunakan algoritma LVQ. Dengan melakukan pengelompokan ini, diharapkan dapat dijadikan sebagi penodam penelitian yang akan dilakukan selanjutnya. 


\section{KAJIAN LITERATUR}

\subsection{Angin Puting Beliung}

Angin puting beliung merupakan salah satu kejadian alam yang dapat dikategorikan sebagai bencana alam. Jenis angin ini di Indonesia kadang dikenal juga dengan istilah angin Puyuh, Lesus (Jawa), Sirit Batara (Sunda). Bila dibandingkan dengan banjir, puting beliung lebih murni disebabkan oleh faktor alam. Faktor alam yang paling berpengaruh pada terbentuknya angin puting beliung adalah dengan adanya perbedaan suhu yang siknifikan atara daratan dengan permukaan udara dekat dengan awan.

Pengamatan yang dilakukan untuk mengetahui perbedaan tersebut dapat dilakukan dengan menggunakan suatu program komputer yang disebut SATAID. Dengan menggunakan SATAID, pengguna dapat menampilkan dan melakukan overlay antara citra satelit dan data NWP. (Harsa dkk 2011).

Penelitian yang didasarkan pada angin puting beliung telah dilakukan oleh Hastuadi Harsa pada tahun 2011 dengan penelitiannya "Pemanfaatan SATAID Untuk Analisa Banjir Dan Angin Puting Beliung: Studi Kasus Jakarta Dan Yogyakarta". Pada penelitian tersebut didapatkan hasil yaitu pada saat terjadi puting beliung Yogyakarta 18 Februari 2007, citra satelit menunjukkan awan dengan pola bulatan yang merupakan konsentrasi awan konvektif kuat yang berpotensi menimbulkan angin puting beliung.

\subsection{Self Organizing}

Self organizing pada jaringan syaraf tiruan yang digunakan dalam penelitian ini adalah learning vector quantization (LVQ). LVQ merupakan suatu metode untuk melakukan pelatihan pelatihan terhadap lapisan-lapisan kompetitif yang terawasi. Lapisan tersebut akan belajar secara otomatis untuk melakukan klasifikasi terhadap vektor input yang diberikan. Apabila vektor input memiliki jarak yang sangat berdekatan, maka vektor-vektor input tersebut akan dikelompokkan ke dalam kelas yang sama. Berikut adalah gambaran jaringan LVQ yang terdiri atas 6 unit lapisan pada lapisan input dan 2 unit (neuron) pada lapisan output.

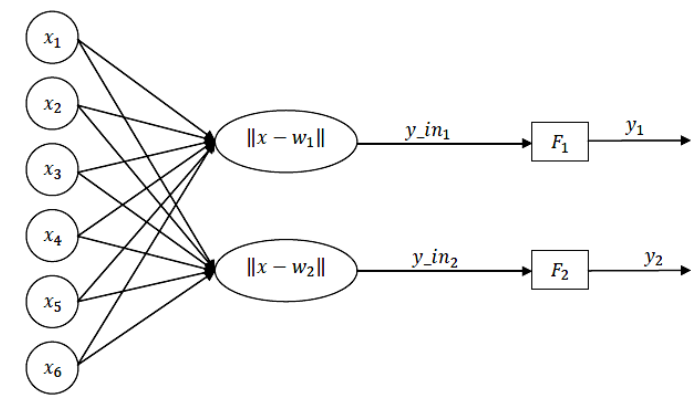

Berikut merupakan algoritma pelatihan yang dilakukan oleh jaringan LVQ jika kita memiliki $n$ buah data dengan $m$ buah variabel input dimana data-data tersebut terbagi dalam $\mathrm{K}$ kelas.

0. Tetapkan:

a. Bobot awal variabel input ke-j menuju ke kelas(cluster) ke-i: $w_{i j} \quad$ dengan $i=\{1,2,3, \ldots . ., K\} \quad$ dan $j=\{1,2,3, \ldots, m\}$.

b. Tentukan nilai maksimum iterasi/epoh: MaxEpoh

c. Parameter learning rate: $\alpha \alpha$

d. Pengurangan learning rate: Dec $\alpha \alpha$

e. Minimal learning rate yang diperbolehkan: Min $\alpha \alpha$

1. Masukkan
a. Data input: $x_{i j}$ dengan $i=\{1,2,3, \ldots, n\}$ $j=\{1,2,3, \ldots, m\}$.
dan
b. Target berupa kelas: $T_{k}$ dengan $k=\{1,2,3, \ldots \ldots, n\}$

2. Tetapkan kondisi awal: epoh $=0$.

3. Kerjakan jika: (epoh $\leq$ MaxEpoh) dan $(\alpha \geq$ $\operatorname{Min} \alpha)$.

a. $\quad$ epoh $=e p o h+1$

b. Kerjakan untuk $\mathrm{i}=1$ sampai $\mathrm{n}$

i. Tentukan $J$ sedemikian hingga $\left|x_{i}-w_{j}\right|$ minimum dengan $j=\{1,2,3, \ldots, K\}$

ii. Perbaiki $w_{j}$ dengan ketentuan

$$
\begin{array}{lll}
\text { - Jika } \quad T=C_{j} & \text { maka } \\
& w_{j}=w_{j}+\alpha\left(x_{i}-w_{j}\right) & \\
\text { - Jika } \quad T \neq C_{j} & \text { maka } \\
& w_{j}=w_{j}-\alpha\left(x_{i}-w_{j}\right) &
\end{array}
$$


c. Kurangi nilai $\alpha$.

Pengurangan nilai $\alpha$ dapat dilakukan dengan cara $\alpha=\alpha-\operatorname{Dec} \alpha$ atau dengan cara $\alpha=\alpha-\alpha$. Deca.

Setelah dilakukan pelatihan akan diperoleh bobot-bobot akhir W. Bobot ini akan digunakan untuk melakukan pengujian atau simulasi. Misalkan kita akan menguji np buah data, maka kita harus melakukan

1. Masukkan data yang akan diuji, misalkan $x_{i j}$ dengan $i=\{1,2, \ldots, n p\}$ dan $j=\{1,2,3, \ldots, m\}$.

2. Kerjakan untuk $\mathrm{i}=1$ sampai np

a. Tentukan $\mathbf{J}$ sedemikian hingga $Q \% x_{i}-w_{j} Q \%$ minimum dengan $j=\{1,2,3, \ldots, K\}$.

b. J adalah kelas untuk $x_{i}$.

\section{METODE PENELITIAN}

Tahapan yang dilakukan pada penelitian ini adalah dengan melakukan studi literatur dan mengkaji permasalahan yang relevan dengan objek yang diteliti, pengumpulan data kejadian yang diteliti, melakukan penormalan dari data yang didapatkan, melakukan pengelompokan awal, dan tahapan terakhir adalah pengolahan data untuk dikelompokka dengan menggunakan algoritma LVQ dengan diimplementasikan kedalam bahasa pemrograman MATLAB.

\section{HASIL DAN PEMBAHASAN}

Data yang diambil dari penelitian ini adalah data kejadian puting beliung yang terjadi di 2 lokasi di Indonesia, yaitu di Surabaya dan Jakarta. Data yang diambil dari bulan Maret tahun 2012 sampai dengan bulan Pebruari tahun 2015. Data kejadian tersebut didapaykan dari http://geospasial.bnpb.go. id/pantauanbencana/data/datatopanall.php. Setelah didapatkan data tersebut, data cuaca yang terjadi pada sekitaran kejadian diakses dari http://www.wunderground. $\mathrm{com} /$.

Data yang didapatkan tersebut, kemudaian dinormalkan dengan ketentuan sebagai berikut:

$$
n(a)=\left\{\begin{array}{c}
0, j i k a \text { tidak terjadi perubahan data } \\
1, j i k a \text { terjadi perubahan data }
\end{array}\right.
$$

Dengan $n(a)$ adalah nilai hasil penormalan data pada baris ke a.

Dari hasil penormalan tersebut, kemudian dilakukan pengelompokan kasar. Pengelompokan kasar yang dilakukan adalah dengan membagi data yang diambil menjadi 4 data kejadian, yaitu a) data saat terjadinya puting beliung, b) data sebelum terjadinya puting beliung, c) data setelah terjadinya puting beliung, dan d) data netral. Data netral yang dimaksud adalah data yang tidak berada pada persekitaran berlangsungnya kejadian angin puting beliung.

Dari pengelompokan kasar tersebut, kemudaian data dibagi menjadi 2 bagian, yaitu data training dan data uji. Data uji dimaksudkan untuk mengetahui, pengelompokan yang dihasilkan oleh simulasi pemrograman algoritma yang diambil apakah telah sesuai dengan yang diharapkan atau tidak.

Implementasi program untuk memisahkan 2 data tersebut dapat dituliskan sebagai berikut

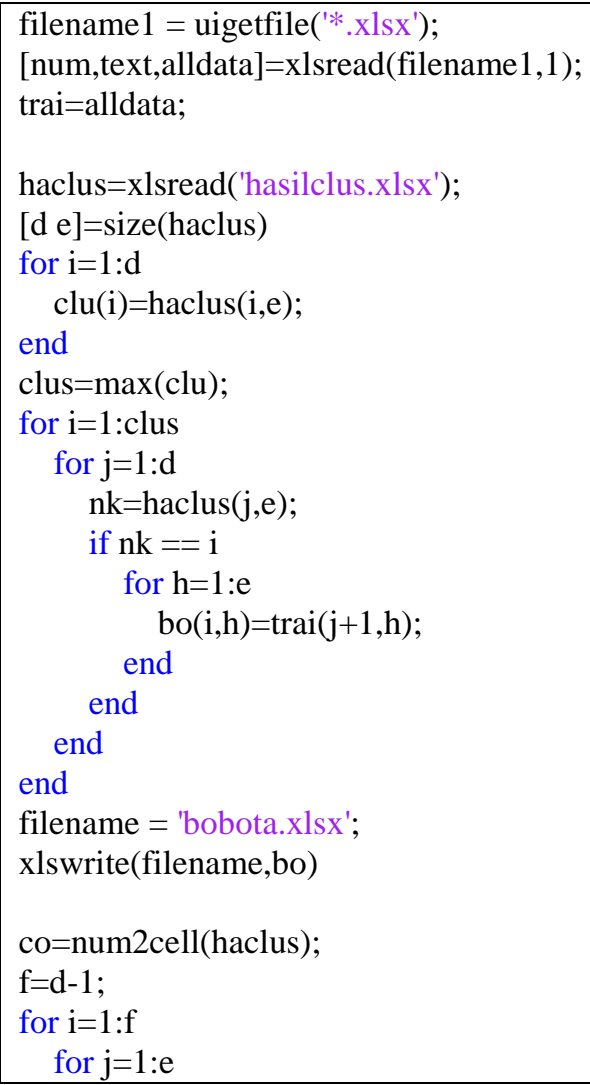




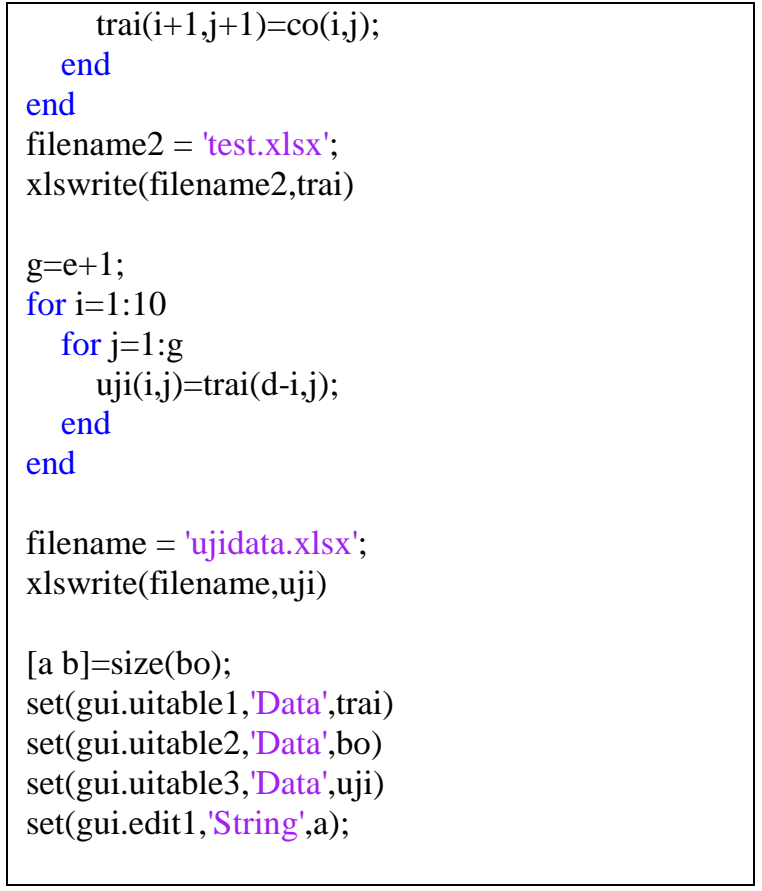

Rangan tampilan dari program iterasi adalah dengan menggunakan GUI yang ada pada MATLAB 2012b. bentuk dari tampilan awal sebagai berikut

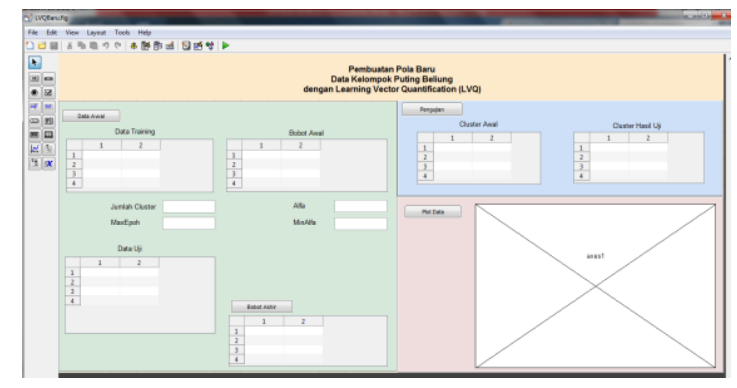

Inti dari implentasi program LVQ yang menghubungkan interface yang telah dibuat dengan menggunakan MATLAB 2012b adalah sebagai berikut

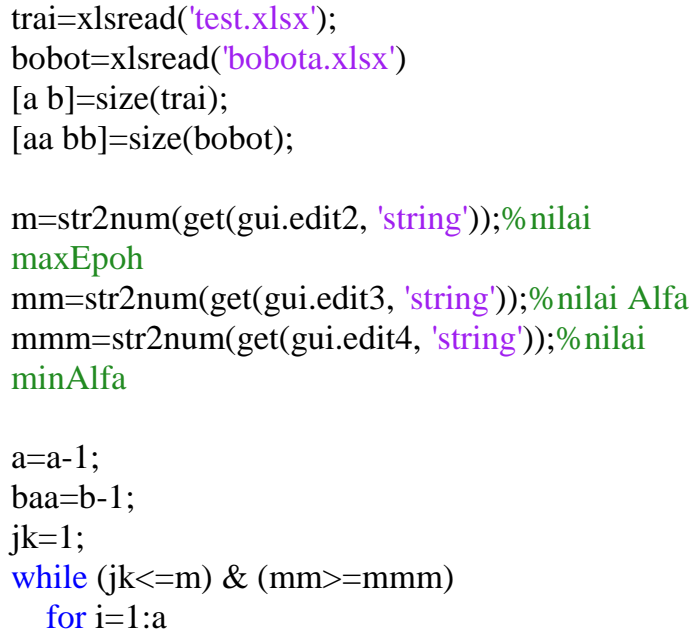

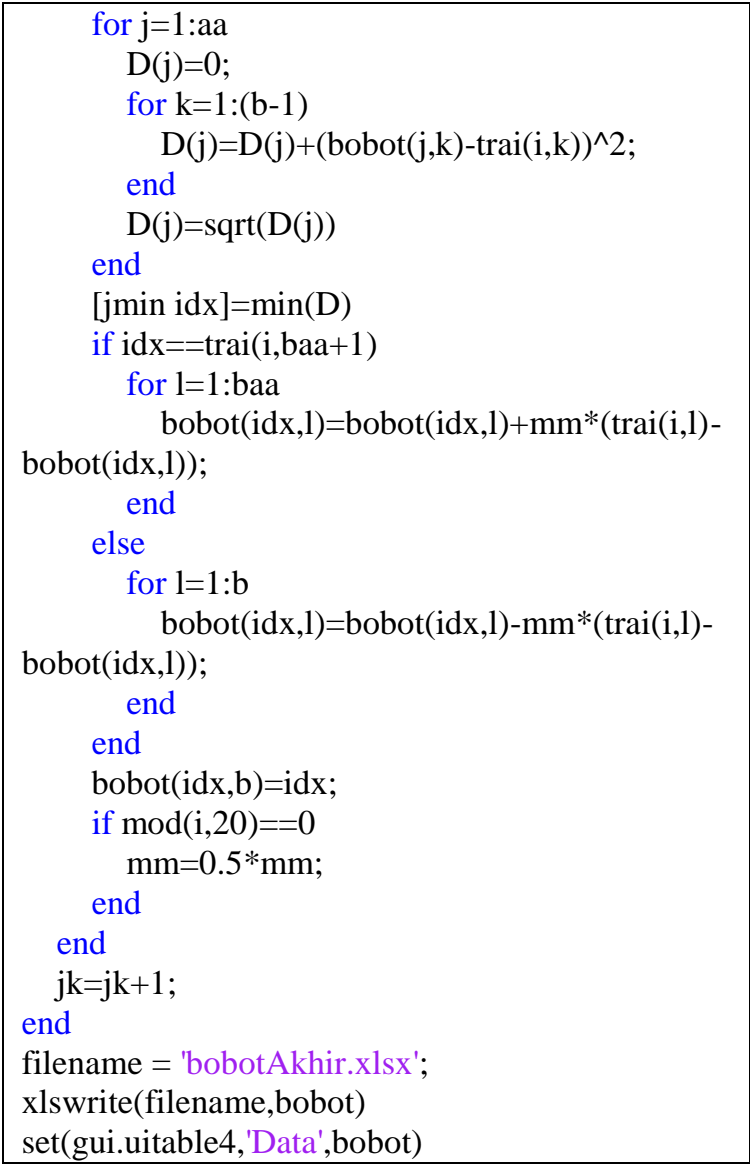

Bobot awal yang diambil yang digunakan dalam proses training diambil secara random dari setiap kelompok data yang telah dibuat. Nilai learning rate $\alpha$ yang diambil adalah 0.001 dengan nilai minimal dari learning rate yang diambil adalah 0.00001. Maksimal iterasi yang dilakukan dalam penelitian ini adalah 1.000.000 iterasi. Besarnya maksimal iterasi bisa dinaikkan.

Setelah dilakukan running program, maka didapatkan hasil sebagai berikut

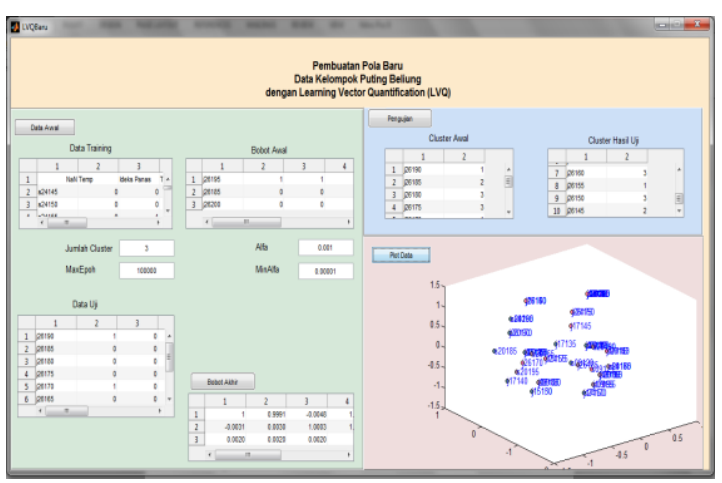

Dari hasil running yang telah dilakukan, semakin kecil nilai min- $\alpha$ yang diambil, maka hasil pembentukan pola yang dibuat akan 
semakin dekat dengan yang diinginkan. Begitu juga dengan nilai iterasi, semakin besar nilai iterasi yang dibuat, maka tingkat ketelitian pola yang terbentuk akan semakin tinggi.

Tetapi kedua hal tersebut berpengaruh pada running time program. Semakin tinggi iterasi dan semakin kecil min- $\alpha$ yang diambil, menyebabkan running time program yang dilakukan akan sangat lama. Hal tersebut disebabkan karena program tidak akan berhenti sampai dengan min- $\alpha$ yang diambil atau mencapai maksimal iterasi yang ditentukan.

Dari hasil running tersebut, maka didapatkan hasil dari data pengujian sebagai berikut

\begin{tabular}{|c|c|c|}
\hline & $\begin{array}{c}\text { Kel } \\
\text { Awal }\end{array}$ & $\begin{array}{c}\text { Kel } \\
\text { Akhir }\end{array}$ \\
\hline $\mathrm{j} 26190$ & 1 & 1 \\
\hline $\mathrm{j} 26185$ & 2 & 2 \\
\hline $\mathrm{j} 26180$ & 3 & 3 \\
\hline $\mathrm{j} 26175$ & 3 & 3 \\
\hline $\mathrm{j} 26170$ & 1 & 3 \\
\hline $\mathrm{j} 26165$ & 3 & 3 \\
\hline $\mathrm{j} 26160$ & 3 & 3 \\
\hline $\mathrm{j} 26155$ & 1 & 1 \\
\hline $\mathrm{j} 26150$ & 3 & 3 \\
\hline $\mathrm{j} 26145$ & 1 & 2 \\
\hline
\end{tabular}

\section{KESIMPULAN}

Dari penelitian yang telah dilakukan, perancangan program yang digunakan untuk melakukan pengelompokan data dan pengenalan pola perlu adanya perbaikan. Hal perbaikan pada program pengelompokan pola ditujukan untuk menemukan pengelompokan yang lebih tepat sebelum digunakan pada program pengenalan pola. Sebaliknya, perbaikan program pengenalan pola diperlukan untuk menemukan pola yang lebih mendekati kejadian nyata serta bisa mengurangi running time yang diperlukan apabila peneliti mengambil nilai min- $\alpha$ yang lebih kecil dan mengambil maksimal iterasi yang lebih besar.

\section{REFERENSI}

Harsa , Hastuadi dkk. 2011. Pemanfaatan SATAID Untuk Analisa Banjir Dan
Angin Puting Beliung: Studi Kasus Jakarta Dan Yogyakarta. Meteorologo dan Geofisika. 12, No 2. 197 - 205.

Kusumadewi, Sri. 2004. Membangun Jaringan Syaraf Tiruan Menggunakan Matlab dan Excel Link. Yogyakarta: Graha Ilmu.

Puslitbang BMKG. 2007. Kajian Cuaca Ekstrim di Wilayah Indonesia. Laporan Penelitian, Pusat Penelitian dan Pengembangan, Badan Meteorologi Klimatologi dan Geofisika, Jakarta.

Puslitbang BMKG. 2009. Kajian Cuaca Ekstrim di Wilayah Indonesia. Laporan Penelitian, Pusat Penelitian dan Pengembangan, Badan Meteorologi Klimatologi dan Geofisika, Jakarta.

Yoshiro Tanaka. (2009). SATAID-Powerful Tool for Satellite Analysis. RSMC Tokyo- Typhoon Center, Japan Meteorology Agency (JMA).

Pantauan bencana. (2015). http://geospasial.bnpb.go.id/pantauanbencana/data/dat atopan-all.php. Diakses tanggal 12 Desember 2015

Weather forecast \& reports. (2016). http://www.wunderground.com/. Diakses tanggal 6 Januari 2016 